Które dzień stwarza, a ty świecisz przez nie:

I jest piękne i promienne w wielkim blasku;

Twoim, najwyższy, jest wyobrażeniem.

Pochwalcny bądź, Panie przez brata naszego kięzyc, i nasze siostry. gwiazdy;

Tyś uksztaltowal je w niebie jasne i cenne i piękne.

Pochwalony bądź, Panie przez brata naszego, wiatr,

I przez powietrze i czas pochmurny i pogodny i wszelki,

Przez kíóre dajesiz tworom swoim utrzymanie.

Pochwalony bądź, Panie, przez siostrę naszą, wodę,

Co pożyteczna jest wielce i pokorna i cenna i czysta.

Pochwalony bądź, Panie przez brata naszego, ogień,

Którym oświecasz noc,

A on jest piękny i radosny i silny i mocny.

Pochwalony bądź, Panie, przez siostre naszą, matkę ziemię.

Która nas żywi i chowa

I rodzi różne owoce z barwnymi kwiaty i zioly.

Pochwalony bądź, Panie przez tych, co przebaczają dla miłości twojej

I znoszą słabość i utrapienie.

Błogosławieni, którzy wytrwają w pokoju,

Grdyż przez ciebie, najwyższy, bedą uwieńczeni.

Pochwalony bądź, Panie, przez siostrę naszą, śmierć cielesną,

Której żaden czlowiek żywy ujść nie może;

Biada tym, co konają w grzechach śmiertelnych;

Błogoslawieni, którzy znajdą się w twej najświętszej woli;

Bowiem śmierć wtóra zła im nie uczyni.

Chwalcie i błogosławcie Pana i czyńcie mu dzięki

I służcie mu z wielkạ pokorą.

\title{
CZY HEBRAJCZYCY BYLI W EGIPCIE
}

T. Milewski, omawiając w swej książce o językoznawstwie zagadnienie języka hebrajskiego, wysunąl następujące twierdzenie: „Nie ule. ga też wątpliwości, że przodkowie językowi Hebrajczyków z epoki klasycznej nigdy w Egipcie nie byli“" ${ }^{1}$ ). Twierdzenie to, jak na pierwszy rzut oka widać, nie da się ograniczyć wyłącznie do zagadnienia początków języka hebrajskiego, ale dotyczy jednego z najważniejszych okresów historii narodu izraelskiego, mianowicie opisanego w księgach:

1) Por. Zarys językoznawstwa ogólnego. II Rozmieszczenie języków, Lublin-Kraków 1948, 165, 
Genesis $(39-41 ; 46-50)$ i Exodus $(1-12,9)$ oraz wielokrotnie wzmiankowanego w Biblii pobytu Hebrajczyków w Egipcie. Zakwestionowanie więc pobytu Hebrajczyków w Egipcie podważa autorytet Biblii i stwarza konieczność naświetlenia tego wczesnego okresu dziejów Izraela na podstawie najnowszych wyników badań naukowych w tym względzie.

Zagadnienie pobytu Hebrajczyków w Egipcie nie jest nowym. Powstało ono jeszcze pod koniec ubiegłego stulecia w związku z zakwestionowaniem wiarogodności Biblii jako źródła historycznego oraz w związku z odkryciem dokumentów klinowych w Tell el-Amarna, w których jest mowa o inwazji ludności Habiru do Palestyny w XV/ XIV w. przed Chr. ${ }^{2}$ ). Wiadomą jest rzeczą, że od czasów H. Gunkela i H. Gressmanna rozpowszechni1 się pogląd, jakoby najstarsze księgi Biblii, zwłaszcza księga Genesis, były zbiorem niehistorycznych opowieści ludowych ${ }^{3}$ ). Wcześniej już J. Wellhausen twierdzil, że biblijny opis najwcześniejszych okresów historii Izraela pochodzi z czasów monarchii izraelskiej (w. IX przed Chr.) i powstal jako odzwierciedlenie istniejących wówczas poglądów ${ }^{4}$ ). Co się zaś tyczy wspomnianych dokumentów z el-Amarna, zawierających korespondencję faraonów Amenofisa III (1405-1370) i IV (1370-1352) z królami babilońskimi, mitannickimi, hetyckimi oraz z władcami palestyńskimi, zależnymi wówczas od Egiptu, wzmiankowanych tam Habiru, którzy, jak wspomniano wyżej, wtargnęli do Palestyny, utożsamiano z Hebrajczykami, pokrewnymi szczepom aramajskim ${ }^{5}$ ), względnie łączono pojawienie się Hebrajczyków w Palestynie z ruchem ludności aramajskiej w latach $1500-1300$ przez Chr. $^{6}$ ).

$\mathrm{Na}$ tle takiego, w pewnym tylko stosunku zgodnego z relacją Biblii, ujęcia początków narodu izraelskiego, niektórzy uczeni, jak na przykład E. Meyer, zakwestionowali opisany przez Biblię pobyt Hebrajczyków w Egipcie. Z drugiej jednak strony, niezależnie od kwestii pochodzenia Hebrajczyków i ich stosunku do wspomnianej już ludności Habiru, większość uczonych zajęła stanowisko przeciwne, odnosząc się jednakże z wielkimi zastrzezeniami co do wiarogrodności odnośnych

2) Por, J, A, Knudtzon, Die El-Amarna-Tafeln, Leipzig 1908. 286, 19; 287, 56 itd.

3) Por. H. Gunkel, Genesis, Göttingen 1917, VII nns.

4) Por. Prolegomena zur Geschichte Israels, Berlin 1886, 331.

5) Por. H. Guthe, Geschichte des Volkes Israel, 'Tübingen 1914, 14; 20.

•) Por. H. Gressmainn, Mose und seine Zeit, Göttingen 1913, 399 ns. 
opisów biblijnych. W rezultacie uczeni, którzy nawet godzili się na pobyt Hebrajczyków w Egipcie, uważali, iz dzieje narodu izraelskiego zaczynają się co najwyżej od wędrówki tychże Hebrajczyków przed ich wejściem do Palestyny (czasy Mojżesza), pomijając tym samym okres wcześniejszy łącznie z epoką patriarchów izraelskich ${ }^{7}$ ).

W roku 1921 A. Mallon opublikował wyczerpującą, opartą na materiale historycznym zaczerpniętym z dokumentów egipskich, monografię o pobycie Hebrajczyków w Egipcie ${ }^{8}$ ). Ostatnio zaś W. F. Albright, znany archeolog amerykański, omawiając początki narodu izraelskiego, wykazał na podstawie zestawienia odnośnych informacji biblijnych z materiałem wykopaliskowym wiarogodność pobytu Hebrajczyków w Egipcie.

W świetle takiego stanowiska nauki w sprawie pobytu Hebrajczyków w Egipcie należy zbadać, czy i o ile wyrażony przez T. Milewskiego pogląd jest słuszny. Ze względu jednakże na ujęcie przez Autora tej kwestii i tok jego rozumowania, wypada zająć się dwoma zagadnieniami, a mianowicie: pochodzeniem Hebrajczyków i wysuniętym w cytowanej książce argumentem językowym, mającym rzekomo świadczyć o tym, że Hebrajczycy nigdy w Egipcie nie byli.

\section{1}

Według Autora, przodkami jezykowymi Hebrajczyków z epoki klasycznej byli ,zdobywcy izraelscy, o których obecności w Palestynie dowiadujemy się po raz pierwszy z napisu Merenptah (1225-1215 przed Chr.)“9). Skąd jednakże ci ,zdobywcy izraelscy" przybyli do Palestyny, Autor nic nie mówi, a tylko w sposób negatywny stwierdza, że w każdym razie nie z Egiptu, przez co zdaje się podzielać wspomniany wyżej pogląd co do lączności tych Hebrajczyków z inwazją ludności aramajskiej.

Niezależnie od nierozstrzygniętej dotąd kwestii stosunku Hebrajczyków do ludności, zwanej Habiru, opierając się na starej tradycji izraelskiej w księdze Genesis (rozdziały: 11-25), przedstawiającej

`) Dodać tu należy, iż w związku ze wspomnianymi dokumentami z elAmarna zwolennicy pobytu Hebrajczyków w Egipcie ustalili date wyjścia Hebrajezyków z tego kraju na w. XV przed Chr. (ok. roku 1448); por. A. Bea, De Pentateucho, Roma 1933, 191.

8) Por. Les Hébreux en Egypte, Rome 1921 (Orientalia nr 3).

9) Por. dz. cyt., 164. 
w formie genealogii, właściwej koczowniczym szczepom semickim, po chodzenie Abrahama-Hebrajczyka i związanych $z$ nim innych grup. ludnościowych, jak Moabici, Ammonici, Izmaelici i Edomici, można w świetle dokumentów z rozkopanego niedawno starożytnego miasta Mari (nad środkowym Euiratem na wysokości Palmiry; z XVIII przed Chr.), tabliczek kappadockich i archiwum Hammurabiego (17921749) odtworzyć środowisko, z którego wyszli Hebrajczycy. Chodzi tu o pólnocno-zachodnią Mezopotamię, ścišlej dystrykt starożytnego miasta Haran (nad rzeką Balich, prawym dopływem Eufratu), gdzie w początkach II tysiąclecia przed Chr., jak świadczą wspomniane wyżej dokumenty, była zgrupowana ludność koczownicza, anorycka głównie. Amoryci ci przybyli do Mezopotanii jeszcze w drugiej polowie III tysiąclecia i, obaliwszy państwo Szumero-akkadyjskie, stworzone przez wcześniej przybylych Semitów (Akkadów), utworzyli szereg małych państw-miast, wśród których wybił się Babilon pod panowaniem zainicjowanej przez Szumu-abu dynastii, do której należał i wspomniany już. Hammurabi (państwo babilońskie). Nie wszystka jednakże ludność amorycka się osiedliła; część jej wraz z ludnością hebrajską i aramajską zgrupowala się w dystrykcie wspomnianego już miasta Haran, skąd stopniowo przesuwała się w kierunku poludniowym na równinę Syrii północnej, zwaną Paddan-Aram.

Najprawdopodobniej z tą ludnością amorycką związani byli He brajczycy (w szerszym znaczeniu), którzy w czasach późniejszych, jak świadczy tradycja staroizraelska (por. Deut. 26, 5), uważali się za potomków „Aramajczyka wędrującego" ${ }^{10}$ ). Wobec wyrażnych aluzji księgi Genesis, która raz po raz podkreśla ścisłą łączność i pokrewieństwo patriarchów izraelskich z Aramajczykami (por. 11, 26. 29; 22, 20 ns.), mieszkającymi właśnie w Syrii pólnocnej (Paddan-Aram: 25, 20; 28, 2. 5. 6. 7; 31, 18), należy przypuszczać, iż pierwotni Aramajczycy nie wiele różnili się od Hebrajczyków; owszem byli, jak to już wspomniano, blisko z nimi złączeni. Według bardzo prawdopodobnego przypuszczenia chodzi tu nie o znanych nam z późniejszych okresów historii Izraela Aramajczyków, ludność koczowniczą, która zaczęła osiedlać się w Syrii w w. XIII przed Chr. (Achlamu); ludność ta bo-

10) Por. podaną w Genesis genealogie, w której Arpakszad, przodek Ebera, jest przedstawiony, jako brat Arama (10, 22-24). 
wiem prawdopodobnie zawdzięczała swą nazwę terytorium, zwanemu (paddan) Aram i przejęła od spokrewnionych z klanem Abrahama Aramajczyków język ${ }^{11}$ ).

W w. XVIII przed Chr., wskutek naporu przybyłej z północy do Mezopotamii ludności indoeuropejskiej, koczownicza ludność semicka (amorycka, aramajska i hebrajska) zaczęła przesuwać się bardziej na południe, docierając poprzez Syrię i Palestynę aż do Egiptu. W czasach tej wędrówki, w ramach której należy pomieścić i wędrówkę klanu Abrahama z Haran do Palestyny i Egiptu ${ }^{12}$ ), występują również niesemici, Hurryci; wędrówka Hurrytów do Syrii i Palestyny stała najprawdopodobniej w związku z opanowaniem w połowie XVIII stulecia przed Chr. Egiptu przez obcych władców, nazwanych po egipsku Hyksosami $\left.{ }^{13}\right)$.

Właśnie na tle trwającego w latach $1750-1580$ przed Chr. panowania Hyksosów w Egipcie oraz okresu, jaki nastąpii po wypędzeniu tychże Hyksosów (czasy panowania rodzimych dynastii egipskich: XVIII i XIX, do czasów Ramzesa II, panującego w latach: 1298-1234), informacje Biblii, dotyczące pobytu Hebrajczyków w Egipcie, nabierają szczególnej wartości historycznej w świetle dokumentów, a zwłaszcza wykopalisk.

Przede wszystkim zrozumialym staje się niezwykle przychylnè przyjęcie, jakiego doznał klan Jakuba-Hebrajczyka, wnuka Abrahama, ze strony faraona-Hyksosa, Syn tegoż Jakıba, Józef, zajmował wówczas wysokie stanowisko namiestnika (wezyra) Egiptu ${ }^{14}$ ) i właśnie dzięki niemu przybyli do Egiptu Hebrajczycy mogli się osiedlic na obfitującym w pastwiska terytorium Goszen (Gessen) we wschodniej Delcie nilowej w pobliżu ówczesnej stolicy państwa Tanis (Awaris).

Według tradycji staroizraelskiej, po dłuższym okresie pobytu.Hebrajczyków w Egipcie pomyślna ich początkowo sytuacja uległa zasadniczej zmianie, gdy na tron wstąpił faraon, który „,nie znał Józefa“. 1948, 184 .

11) Por. W. F. Albright, From the Stone Age to Christianity, Baltimore

12) Por. T. J. Meek, Hebrew Origins, New York-London, 1956, 14 nns.

${ }^{13}$ ) Por. E. A. Speiser, Ethnic Movements in the Near East in the Second Millenium B. C. The Hurian and their connections with the Habiru and the Hyxos, art. w Annual of the American School of Oriental Research 13 (1931) $13-54$.

${ }^{14}$ ) Por. E. Drioton - J. Vandier, Egypte, Paris 1938, 177 ns. 
Rozpoczęło się wtedy długotrwałe prześladowanie ludności hebrajskiej (zmuszanie do ciężkich robót przy budowie względnie przebudowie miast Ramesses i Pitom; eksterminacja ludności przez uśmiercanie lub topienie noworodków płci męskiej itp.).

Ta zmiana położenia Hebrajczyków w Egipcie miała niewątpliwie swe uzasadnienie w wydarzeniach, jakie zaszły w latach $1580-1280$ przed Chr.

Około bowiem roku 1560 przed Chr. Ahmose I, założyciel rodzimej, XVIII-ej, dynastii egipskiej, zdobył stolicę Hyksosów Tanis (Awaris), rozpoczynając walkę o wyzwolenie Egiptı spod okupacji Hyksosów. Wladcy hyksoscy zostali wypędzeni z Egiptu, pozostała zaś ludność semicka, a więc i Hebrajczycy, znienawidzona z racji swego pokrewieństwa z Hyksosami przez Egipcjan, zeszła do roli niewolników. Wraz $\mathrm{z}$ wypędzeniem Hyksosów rozpoczął się okres egipskiego podboju $\mathrm{Pa}$ lestyny i Syrii. Tutmose III (1490-1436) i jego następca Tutmose IV (1423-1413) prowadzili wojnę $z$ państwem Mitanni (Mezopotamia centralna) o wpływy na Bliskim Wschodzie. Gdy okolo roku 1370 państwo Mitanni zostało podbite przez Hetyłów, egipska sfera wpływów w Syrii zetknęła się z kolei z nowym imperium hetyckim. Przez 50 lat, tj. do roku 1320, obie potęgi: egipska i hetycka unikały konfliktu, organizując się wewnętrznie i szykując się do ostatecznej rozprawy. Wojna Egiptu z Hetytami wybuchła za panowania faranna Seti I (13191298) i przeciągnęla się na panowanie Ramzesa II (1298-1234), à do zawarcia pokoju w roku 1280.

Rzecz zrozumiała, że w tym okresie konfliktów Egiptu najpierw z Mitannitami a później z Hetytami, obecność obcego elementu semickiego we wschodniej części Delty nilowej (terytorium Goszen) była, ze względu na bliskość wschodniej granicy państwa wysoce niepożądana; granica ta bowiem mogłaby być w razie porażki Egiptu w walkach z Mitannitami czy Hetytami bardzo zagrożona. Na to więc wschodnie pogranicze Egiptu, tak ważne pod względem strategicznym, zwłaszcza, że tu również leżało założone przez Hyksosów miasto Tanis (Awaris), które i za czasów Ramzesa II było stolicą państwa ${ }^{15}$ ), szczególną zwracano uwagę. Tu też wznoszono fortyfikacje i budowano magazyny nadgraniczne dla zaopatrzenia wojska.

Wykopaliska, prowadzone we wschodniej' części Delty nilowej, w Tell Ratabeh (biblijne Pitom; por. Exod. 1, 11) i na terytorium daw-

$\left.{ }^{15}\right)$ Por. W. F. Albright, dz. cyt., 194; 196. 
nego miasta Tanis, potwierdziły biblijną relację o budowie, względnie przebudowie, miast nadgranicznych za panowania laraona Ramzesa II. Podana przez Biblię nazwa drugiego miasta - Ramesses (Exod 1, 11), w związkı z opisem ucisku Hebrajczyków, również nie nastręcza poważniejszej trudności. Stwierdzono bowiem, że hyksoska niegdyś stolica Tanis (Awaris), była, jak już wspomniano również i za czasów faraona Ramzesa II stolicą państwa egipskiego, w latach zaś 1300-1100 miasto to nosilo nazwę Per-Ro'emasese (,dom Ramzesa") "').

W ten sposób relacja biblijna zarówno o pobycie Hebrajczyków w Egipcie, jak i o ich prześladowaniu przez laraonów, mimo swej szczupłości, znajduje potwierdzenie w dostępnym nam dzisiaj materiale historycznym.

Z kolei należy rozpatrzyć zarzut co do braku jakichkolwiek wzmianek o pobycie Hebrajczyków w Egipcie. W dokumentach jednakże z czasów faraonów Seti I (1319-1298) i Ramzesów II, III i IV występuje nazwa 'prw, którą określano robotników, zatrudnionych zwłaszcza przy budowie. Istnieje więc przypuszczenie, iż nazwa ta oznacza Hebrajczyków ${ }^{17}$ ). Ponieważ jednakże wyjście hebrajskiego klanu Jakuba z Egiptu nastąpiło już około roku 1290, czyli za Ramzesa II, obecność tej ludności w czasach późniejszych jest rozumiana w tym sensie, że chodzi tu o jeńców wojennych lub reemigrantów z Palestyny $\left.{ }^{18}\right)$. Bar dziej prawdopodobne jest przypuszczenie, iż mianem Hebrajczyków Egipcjanie określali w ogóle ludność semicką, jaka pozostała w kraju faraonów od czasu Hyksosów. Część tej ludności stanowiliby Hebrajczycy, potomkowie Jakuba, którzy wcześniej już opuścili Egipt ${ }^{10}$ ).

Wobec niewątpliwie uzasadnionego faktu pobytu Hebrajczyków w Egipcie należało by w ostatecznym wniosku stwierdzić, że wspomniani przez T. Milewskiego ,najeźdźcy izraelscy“ z czasów faraona Merneptaha byli to Hebrajczycy, którzy nieco wcześniej rozpoczęli pod dowództwem Jozuego podbój Palestyny. We wspomnianym już napisie tego faraona (stela Merneptaha) przy nazwie ,Izrael“ znajduje się egipski determinatyw, nadający tejże nazwie znaczenie „ludność“,

16) Por. W. F. Albright, dz. cyt., 196.

${ }^{17}$ ) Por. G. A. Danell, Studies in the name-Israel in the Old Testament, Upsala 1946, 45.

$\left.{ }^{18}\right)$ Por. J. W. Jack, The Date of the Exodus in the Light of External Evidence, Edinburgh 1925, 257 nns.

$\left.{ }^{19}\right)$ Około roku 1890 przed Chr.; por. Ruch Biblijny i Liturgiczny, (1949) $370 \mathrm{nns}$. 
a nie ,terytorium“ ${ }^{20}$ ), co wskazywałoby, iż przybysze ,,izraelscy“ byli "wówczas dopiero $\mathrm{w}$ stadium zdobywania Palestyny, jak to wyżej wspomniano.

O walce Izraelitów z wojskiem egipskim za czasów Jozuego Biblia milczy. Ma to niewątpliwie swe uzasadnienie w sytuacji politycznej Egiptu, jaka wytworzyła się pod koniec Ramzesa II i za następców tego faraona. Mianowicie Egipt zaniechał wówczas polityki interwencji w sprawy Azji Przedniej ze.względu na wielkie niebezpieczeństwo, grożące ze strony Libii. Wprawdzie Merneptahowi udało się w roku 1220 pokonać szczepy libijskie, co właśnie zostalo upamiętnione na wspomnianej steli; jednakże, jeśli chodzi o wyprawy wojenne tego laraona do Azji (Palestyna, Syria, Hatti), istnieje wśród uczonych pogląd dość sceptyczny. Niektórzy przypuszczają, iż dokument ten jest wyrazem chełpliwości Merneptaha ${ }^{21}$ ).

W związku ze wspomnianym dokumentem Merieptaha należy uwzględnić jeszcze zagadnienie stosunku nazwy „Hebrajczycy“ do nazwy „Izraelici“. Jest to zagadnienie trudne do rozwiązania. Wiadomą jest rzeczą, że w Biblii nazwa „Hebrajczycy“ w znaczeniu „Izraelici" występują wtedy, gdy o Izraelitach mówią cudzoziemcy, lub gdy sami Izraelici mówią o sobie w rozmowie z cudzoziemcami ${ }^{22}$ ). Fakt ten nasuwałby przypuszczenie, iż nazwa "Hebrajczycy“ była bardziej ogólna i wcześniejsza w stosunku do nazwy „Izraelici". Jaka jest jednakże geneza i znaczenie tej ostatniej nazwy, nie udalo się dotąd, pomimo wielu prób, ustalić. G. A. Danell wyraził przekonanie, iż Hebrajczycy, przybywszy po swej wędrówce na Synaju do Palestyny, połączyli się ze szczepami, zjednoczonymi przez szczep) Aser (nazwa jednego $z$ dwunastu synów Jakuba) i że od tej właśnie nazwy Aser pochodzi nazwa. Izrael ${ }^{23}$ ).

Aczkolwiek supozycja taka co do pochodzenia nazwy Izrael nasuwa poważne zastrzeżenia, pozwala ona jednakże mniemać, iż nazwa „Hebrajczycy", bardziej ogólna, dotyczyła ludności semickiej, wędrującej w czasach Abrahama z pólnocno-zachodniej Mezopotamii do Syrii, Palestyny i Egiptu. Grupa tej ludności - klan Abrahama - otrzymała być może z czasem nazwę „Izrael“, utożsamioną w Genesis 32,

$\left.{ }^{20}\right)$ Por. W. F. Albright, dz. czyt., 194.

$\left.{ }^{21}\right)$ Por. E. Drioton - J. Vandier, dz. czyt., 414 ns.

${ }^{22}$ ) Por. Exod. 1, 15. 16. 19; 2, 6. 7. 11. 13; oraz 3, 18; 5, 3; 7, 16; 9, 1.

${ }^{23}$ ) Por. G. A. Danell, dz. cyt., 45 ns. 
23-33 z Jakubem. Potomkowie Jakuba, ,Izraelici“, którzy w czasie swego 430-letniego pobytu w Egipcie rozrośli się do rozmiarów pokaźnej grupy ludnościowej, wróciwszy do Palestyny, połączyli się z mieszkającą tam ludnością hebrajską. W ten sposób powstałby na ród „izraelski“, podobnie, jak ze zlania się przybyłej z północno-zachodniej Mezopotamii ludności hebrajskiej z ludnością peryferii Palestyny powstały takie narody, jak Moabici, Ammonici czy Edomici.

2 .

Jeśli chodzi o argument językowy, wysuwany przeciwko faktowi pobytu Hebrajczyków w Egipcie, należałoby uwzględnić zagadnienie genezy języka hebrajskiego. Zagadnienie to jednak ze względu na swój charakter wykracza poza ramy niniejszego artykułu. Dlatego też ograniczymy się do ogólnych tylko danych, kładąc główny nacisk na samą trudność wynikającą rzekomo z racji językowych, jeśli chodzi o przyjęcie wiarogodności relacji biblijnej o pobycie Hebrajczyków w Egipcie.

T. Milewski wyraził twierdzenie, iż wspomniani już „Zdobywcy izraelscy... przyjęli język podbitej ludności, zmieniając go tylko w drobnych szczegółach. Natomiast jakim językiem mówili dawniej ci zdobywcy, dia!ektem kananejskim czy aramejskim, rozstrzygnąć niepodobna“" $\left.{ }^{24}\right)$.

Jest rzeczą wiadomą, iż język hebrajski jest najbardziej zbliżony do kanaańskiego, ten zaś należy do zachodnio-semickiej grupy językowej. $Z$ drugiej jednak strony, jak wynika $z$ imion własnych i słów, występujących w dokumentach z Mari, a także $z$ imion i nazw geograficznych w dokumentach egipskich z epoki Hyksosów, w czasach wędrówki Abrahama (w. XVIII), najbardziej rozpowszechnionym był dialekt za. chodnio-semicki, którym najprawdopodobniej mówili zarówno Hebrajczycy, jak i spokrewnieni z nimi „Aramejczycy“ (różni od Aramejczyków późniejszych). Po osiedleniu się w Palestynie Hebrajczycy przyjęli lokalny dialekt kanaański, skutkiem czego powstał język hebrajski.

Po tym ogólnym stwierdzeniu przystąpmy do właściwego zarzutu językowego, sformulowanego przez Autora w następujących słowach: „W klasycznej hebrajszczyźnie mamy najwięcej, bo okolo setki, wyrazów zapożyczonych $z$ akadzkiego, podczas gdy zapożyczeń z egipskie-

${ }^{24}$ ) Por. dz. cyt., 164. 
go jest zaledwie kilkanaście. Odpowiada to stosunkom panującym w Kanaanie w drugim tysiącleciu przed Chr., gdy językiem kraju był akadzki, a ekspansja polityczna Egipcjan byla połączona tylko z drobnymi postępami ich języka" ${ }^{25}$ ).

Istotnie przyznać należy, iż ślady języka egipskiego w Biblii są znikome, jednakże wniosek, do jakiego doszedl Autor na tej podstawie, negując pobyt Hebrajczyków w Egipcie jest zbyt daleko posunięty. Istnieją bowiem racje, które ten brak wpływów języka egipskiego na język hebrajski całkowicie usprawiedliwiają.

Zanim przejdziemy do uwzględnienia tych racji, zwróćmy uwagę na niewątpliwie egipskie pochodzenie imion własnych, występujących w Biblii, jak: Mojżesz, Hofni czy Finees ${ }^{26}$ ). Oczywiście okoliczność nie może przesądzać kwestii wpływu języka egipskiego z uwagi na wpływy Egiptu na Palestynę; nie mniej jest ona dość ważna. Hipoteza natomiast, którą wysunął A. S. Yahuda, co do silnego wpływu języka egipskiego na język hebrajski Biblii ${ }^{2 \top}$ ), nie jest przekonywująca ze względu na zbyt apologetyczny i tendencyjny charakter opublikowanej przez niego pracy ${ }^{28}$ ).

Wspomniany wyżej brak wplywów języka egipskiego na język hebrajski Biblii znajduje swe uzasadnienie w następujących okolicznościach.

Przede wszystkim w tym, że jak już wspomniano, za czasów panowania Hyksosów Egipt był, jeśli tak można powiedzieć, ,zsemityzowany". Swiadczą o tym skarabeusze $z$ w. XVIII przed Chr., na któryci występują imiona semickie) jak na przykład: Ja'ą̨ob-har; odpowiednik biblijnego „Jakub“), a zwłaszcza nazwy geograficzne, jak: Sukkot, Migdol, Baal-Sefon czy może nawet Goszen ${ }^{29}$ ). Powtóre Hebrajczycy, osiedleni na terytorium Goszen, żyli w odosobnieniu od reszty kraju, tworząc swego rodzaju getto. Dzięki temu zdolali w ciągu przeszło 400 lat zachować swą odrębność narodowościową, religijną oraz językową. Zresztą, jak to wynika z księgi Genesis, nie zatracali łączności z Palestyną.

25) Tamże.

26) Por. W. F. Albright, dz. cyt., 150: 185.

27) Por. A. S. Yahuda, Die Sprache des Pentatench in ihren Beziehungen zum Aegyptischen, Berlin-Leipzig 1929.

28) Por. P. Dhorme, Rerue Biblique 58 (1929) 441-445.

29) Por. W. F. Mlbright. 1\%. c.yt., 184. 
Powtóre istnieje inna jeszcze okoliczność, która w pełni wyjaśnia brak wpływów języka egipskiego na język hebrajski.

Obecnie uczeni, opierając się na dokumentach z Mari, Boghazköi i el-Amarna, określają lata 1600-1200 przed Chr. epoką pierwszego internacjonalizmu na starożytnym Bliskim Wschodzie. Wtedy to bowiem wpływy, zarówno religijne, jak i literackie Mezopotamii objęły nie tylko kraje najbliższe, ale również i Egipt. Nastạpiło to dzięki niezwykle silnej ekspansji języka akkadyjskiego, który stał się francuszczyzną ówczesnego Bliskiego Wschodu. Dość powiedzieć, że faraonowie egipscy korespondowali z Babilończykami, Mitannitami czy Hetytami w języku akkadyjskim. Co więcej, w tym samym języku utrzymywali korespondencję ze swymi wasalami w Palestynie i Syrii, jak o tym świadczą wspomniane już dokumenty z el-Amarna ${ }^{30}$ ). Czyż wobec tego można się dziwić, że istnieje przewaga wpływów akkadyjskich na język hebrajski?

Wreszcie, biorąc pod uwagę w bardzo lakoniczny sposób przedstawiony w Biblii pobyt Hebrajczyków w Egipcie, oraz fakt, że język hebrajski, w którym zostały spisane księgi Starego Testamentu w czasach stosunkowo późnych, w każdym razie już w czasach klasycznego języka hebrajskiego ${ }^{31}$ ), możemy przypuszczać, iż ślady wplywów języka egipskiego na język hebrajski mogły się stopniowo zatrzeć. Przypuszczenie to jest tym słuszniejsze, że $z$ jednej strony nie znamy języka, jakim mówili Hebrajczycy po powrocie do Kanaanu, a z drugiej, że tradycja religijna Izraelitów, która stanowiła podstawe znanych nam dzisiaj ksiąg historycznych Starego Testamentu, była najprawdopodobniej przechowywana starannie w języku hebrajskim, chronionym od wszelkich obcych wpływów.

Kwestionowanie więc historycznego faktu pobytu Hebrajczyków w Egipcie ze względu na pewne racje językowe, zwłaszcza wobec braku danych co do poszczególnych etapów rozwoju języka hebrajskiego, znanego nam jedynie $z$ jednego dokumentu, jakim jest Biblia, byłoby więc zbyt ryzykowne.

Słusznie stwierdził A. Lods, iż trudno byłoby nazwać fikcją czy tworem sztucznym biblijny opis upokarzającego pobytu Hebrajczyków w Egipcie ${ }^{32}$ ). Pobyt Hebrajczyków w Egipcie jest tak ważnym okre-

30 ) Por. W. F. Albright, dz. cyt., 158 nns.

31) Por. T. Milewski, dz. cyt., 164.

32) Por. Tsraël des origines au milieu du Vllle siècle, Paris 1950, 192. 
sem $w$ dziejach narodu izraelskiego, że pominięcie go stwarzałoby nie dającą się niczym zapelnić lukę $\left.{ }^{33}\right)$.

\section{Warszawa}

KS. CZESEAW JAKUBIEC:

\section{ODPOWIEDŹ}

Redakcja RBL poprosila profesora Un. Jag. T a de us z a M ilewskiego, aby był laskaw wypowiedzieć się co do zagadnienia poruszonego. Oto odpowiedź, jaką nam nadesła1:

Zarzuty ks. Jakubca zwrócone przeciwko pewnym ustępom mojej książki wynikają w znacznej mierze $z$ nieporozumienia co do znacze nia terminu ,przodkowie językowi“", których należy starannie odróżnić od przodków biologicznych. Nasi przodkowie językowi to ludzie minionych pokoleń mówiący językiem, którego mniej lub więcej przekształconą formę stale używamy. Mogą być oni naszymi przodkami biologicznymi ale nie jest to zupełnie konieczne. I tak np. przodkami językowymi dzisiejszych Francuzów są mieszkańcy miasta Rzymu $z$ ostatnich wieków przed Chr., podczas gdy ich przodkami biologicznymi są mieszkańcy starożytnej Galii i Germanii. Całe plemiona niekiedy przyjmują nowy język i wówczas ich przodkowie językowi odcinaja się ostro od przodków biologicznych. Przodkami biologicznymi Hebrajczyków z epoki klasycznej była z jednej strony stara ludność Kanaanu, z drugiej najeźdzcy, którzy wtargnęli pod wodzą Jozuega. Zdobywcy ci przebywali przez dłuższy czas w Egipcie, jak tego dowodzą argumenty ks. Jakubca w sposób zupełnie przekonywujący. Powstaje jednak pytanie, która z tych dwu grup była przodkiem językowym Hebrajczyków z epoki klasycznej. Otóż wszystko przemawia za tym, że przodkiem tym był język ludności podbitej. Język hebrajski jest bardzo bliski językowi fenickiemu a zwłaszcza moabickiemu, które są: siadują z nim bezpośrednio. Zgadza się on również z tymi dokumentami dialektów starokanaanejskich z II tysiąclecia przed Chr., które do nas doszły. Wszystko to dowodzi, że język hebrajski jest częścią grupy kanaanejskiej, która od wieków zajmowała Palestynę i kraje sąsiednie. Wielka ilość zapożyczeń akkadzkich nie może dziwić w języku

${ }^{33}$ ) Por. W. F. Albright, dz. cyt., 183: „'The Egyptian sojourn of Israel is a vital part of early Israelite historical tradition, and be eliminated without leaving an inexplicable gap". 